\title{
Mothers Perception, Attitude, and Willingness to Purchase towards Baby Formula
}

\author{
*Febrina Fitriyanti Tambunan, Mustika Sufiati Purwanegara, Mia Tantri Diah Indriani \\ Institute Technology Bandung, Indonesia \\ *febri.tambunan@sbm-itb.ac.id
}

\begin{abstract}
There is abundance of baby formula brand in Indonesia's market. To capture reasonable share in these lucrative businesses, it is imperative that producers have to remain competitive. Advertisements in a variety of media is being recognized as a method to communicate products to a wider target audience but empirical research also shown that consumers are sceptical of such claims. The purpose of the paper is to identify customer perceptions and attitude towards baby formula and their willingness to pay. The preliminary qualitative study was conducted by focus group discussion and sentence completion technique. The quantitative study is expected to validate the findings. Questionnaires are distributed to total 105 mothers who have baby at $0-5$ years old, where hypothesis were tested with multivariate analysis. The result shows that growth benefit made by baby formula significantly influence the willingness to purchase baby formula. The mothers stated that baby formula is considered as substitute for breast milk only, giving nutrition for baby but does not build baby's intelligence as claimed in many advertisements. The implication of this research is valuable for marketer to understand consumer preferences and perspective on baby formula purchase.
\end{abstract}

Keywords: baby formula; consumer perception; brand position; willingness to purchase; health claims

\section{Introduction}

Consumers of baby formula always expose to the advertisement that showing how babies become genius after consuming baby milk formula from certain brands. Baby formula companies use a variety of traditional and online media to advertise their products to capture wide target audience. Research shows that consumer's ability to memorize certain brand and to put them in the top of mind as the effect of advertisement disclosure that they could not control when its expose on TV (Mazis et al., 2007). To establish brand image, advertiser use media as the best method of one-way communication campaign to its audience, television commercials use to visualize product, print advertisement employ to expose more detail information and finally product packaging use to draw consumer attention at the point of purchase (Schultz, Tannebaum and Lauterborn, 1993). There is abundance of baby formula brand in Indonesia's market and to capture reasonable share in these lucrative businesses, it is imperative that producers have to remain competitive. To build and maintain good brand image through aggressive advertisement has been recognized as the fastest way to communicate the product. According to Okazaki et al. (2007) positive image towards brand affect of consumer trust. Moreover, Fishbein and ajzen (1975) stated that when consumer has positive brand attitude toward product it would increase the consumer purchase intention. Nevertheless empirical research also shown that consumer is sceptical about the claims showed in advertisement. Consumers know that commercials are meant to persuade and believes to be untruthful in general. Moreover, scepticism of health claims is higher when the sources of information are from advertisement (Mazis et al., 2007).

Indonesia as the fourth largest population in the world, according to Indonesia Statistical Centre 2012, there is about 4, 6 million women who give birth for the first time every year. Baby formula is a synthetic version of breast milk and classified as dairy substitutes. Dairy substitutes have been used since the early nineteenth century for products like oleomargarine and filled cheese. They are made by blending fats, proteins, and carbohydrates using the same technology and equipment used to manufacture real dairy products. Since the 1940s, advances in processing techniques such as homogenization, fluid blending, and continuous batching and filling have greatly improved the ways to imitate dairy products. The sales of infant formulas have also improved over the last several decades. Until the early 1990s, infant formula was sold only as a pharmaceutical product. Sales people presented their brands to pediatricians who would then recommend the products to new mothers. Now, manufacturers shift their marketing strategies toward more direct marketing techniques. Now, in addition to pharmaceutical sales, manufacturers rely heavily on direct mail campaigns and TV and print advertising to recruit new customers (Ball and Wright, 1999). There are many research finding and theory on consumer decision 
journey, what and how perception shaped in consumer mind and factors influencing consumer behaviour and their willingness to purchase product and service. There is, however, little research on marketing for baby formula. Mothers and their significance in baby products industry, has unique emotional behavioural qualities. For mother there is a genuine need to decide the right thing for their babies, their perception and attitude toward baby formula that looking for safety, nurturing, and benefit for the baby are the dominant attributes to consider.

While advertising has more and less shaped mother's perception and attitude toward baby formula, their purchase decision is not entirely based on information from the advertising or other means of marketing communication. Their best interest is always the safety and health of their babies therefore other factors might play significant roles in purchase decision, such as expert opinion, other mother's experience, baby preference, etc. This paper focuses on the study of mother's behaviour toward baby formula in general under the influence of many information that are presented today through different kinds of media by the producers. This study seeks to determine mother's most influence factor to purchase baby formula and to identify mother's perception towards baby formula.

\section{Literature Review}

Brand Position: When companies design the product position, they will plan and design them as value proposition to offer to its consumer. According to Moorman (1996) in order to gain greatest advantage in market, marketer must (1) Plan the product positioning in selected target market and (2) Crafting marketing mixed to execute the plan according to desire. Fournier (1998) define trust by consumers' is the "willingness to rely on the ability of the brand to perform its stated function". The commitment to certain brand is the result of trust and belief on one product. Trust toward a brand will directly affects favorable attitudes and behavior (Hans et al., 2011). The authors identify specific types of brand positioning that increase brand equity and category price sensitivity; those are health and benefit claim and price, this brand positioning purpose to effect the perception of mother towards baby formula.

Brand Positioning on Health and Benefit Claims: One way to increase purchase intention for food consumer are by labeled food with health claims in purport that the consumer will get health benefit by consuming them. Generally, health claims deal with the concern of trust, ease of interpretation and clearness of the health claims Levy (1995). Even though consumer frequently doubt of such claims, they found health claims are helpful in making decision. Research by Calfee, and Pappalardo (1991) also support the statement that health claims on food label give favorable behavior on consumer even though they skeptic to the genuinely of the claims. Burton et al. (1994) found that additional nutrition information exaggerated nutrition attitudes, perceptions, and increase purchase likelihood. Individual difference variables, such as nutrition consciousness, motivation to process nutrition information, and nutrition knowledge, may affect consumers' perceptions, processing, and evaluations of nutrition information offered on product packages. When faced with a complex decision environment, peripheral cues or heuristics can reduce the effort needed in processing nutrition information and allow the consumer to make judgments and evaluations based on the simplified cue or heuristic. As shopping aids, food labels add to consumers' information base and help guide buying decisions (Eagly and Chaiken, 1993, p. 330).

Nutrition claim in the label has an important role in communicating what the manufacturer want to promote to its consumer. Producer use traditional mass media such us articles, radio, newspaper and television are widely used to communicate the nutritional message to wide target of consumer. They also employed health practitioners (including doctors, nurse, and healthcare workers), books, and teaching materials and through food packaging to campaign, the distinction of their product through the health claims (Caswell et al., 2003; Roe and Sheldon, 2007). In addition, for claims for baby formula products, based on the finding of our qualitative study, the respondent thought that baby formula with health claim is safer compare with those without health claim. Though they even do not fully understand the meaning of each health claim but they trust them, some respondent thought that health claim is marketing trick but somehow sophisticated claims in the label attract them to purchase.

Positioning strategies on consumer price sensitivity: Price is one of the most important elements affecting to products and services. Price consciousness is related to the price acceptance level as well as to the width of latitude of product acceptability (Lichtenstein et al., 1988). Producers and marketer must be aware of the consumer perceived of value of one product. Consumer values refer to their product 
attributes view versus other product attributes. Consumer experience about product and service will formed the consumer price perception. According to Laroche and Howard (1980) price merely as the symbol of financial value, that consumer agrees to give to the vendor during the purchasing process. Consumer price perception- more or less- is a result of their perception of quality, benefit, value and personal beliefs. Although individuals who are price conscious are generally not willing to pay higher for the product they consider not worth their value, as mother want to give the best product for their baby we want to test if perceive price will affect the attitude and willingness to pay toward baby formula. Income was found directly related with consumer willingness to pay for a products or service. Higher income indicates the person to be positively willing to pay for an extra price and to pay for superior quality of product. (Misra et al., 1991; Van, Ravenswaay and Hoehn, 1991; Underhill and Figueroa, 1996; Angulo et al., 2005; Govindasamy et al., 2005; Posri et al., 2007). The positive effect of income indicates that consumers with a higher income are willing to pay an extra price and buy these types of food products (Tsakiridou et al., 2006). From the qualitative study, mothers perceived baby formula as expensive product and only buy the affordable brand for the babies. Low price baby formula is preferable as long as the baby likes. Thus, we hypothesis:

\section{H1: Brand positioning effect willingness to purchase baby formula}

Perceived Quality: The understanding of quality is depending on the users. Quality expression is very ambiguous depend on the background of the person using this expression (Becker and Tilman, 2000). According to The total quality management literature: quality defines as conformance to requirements", fitness for purpose". This definition related to the definition of German Association for Quality: "Quality is the entirety of features and characteristics of a product, which refers to the fitness to fulfill given needs" (Juran, 1979). It is important to define quality from consumer orientation; the perspective of quality on baby formula can be very different from other type of milk powder. According to Fournier (1998) the context of quality is delicate because rely on consumer judgment on the product performance, which it will superior or excellent. Perceived quality is form from the individual judgment of the quality cues and attribute of the product. From the finding of qualitative study, the mothers perceived that high quality baby formula is those imported brand and expensive whereas low quality baby formula are those manufactured locally and lower price. Based on this finding, hence we hypothesize:

\section{H2. Perceived quality is significantly related to willingness to purchase towards baby formula}

Baby Formula Benefit: It is every mother natural default instinct to breastfeeding their infants. Every time a baby breastfeed they will get numerous benefit from the milk for the growth and development of baby, such us active enzymes, antibodies. Not only as the source of energy for their first six month of life but also provide active immunity for protection from disease. Breast milk also contains hormones, live cells that will never provide by cow based baby formula (Gartner et al., 2005). However, some mother found it is impossible to exclusively feed their baby with breast milk, one of the reason is she produce little breast milk, death, sickness, disease, separation, physiological problems. Baby formula industries captured this reason and provide the substitution of breast milk with cow-based milk formula (Anne, 2011). The phenomena of global economy integration that lead to modernization in Indonesia, women are moving into the paid workforce. For this reason baby formula are needs as substitute for breast milk. Scientist of baby formula industry applied the known substance of breast milk as their general reference to develop infant formulas. In general, baby formula contains this following raw material: vitamins, minerals, proteins, diluents, fats, emulsifiers, carbohydrates and stabilizers. Understanding the highly complex nature of the biological needs of an infant, the design of baby formula also crafted as similar as possible to the physical and benefit properties of breast milk. According to Gartner et al. (2005), baby formula can derive from three categories of milk-based formula they are vegetable-based formula, animal-based formula and non-milk based. Furthermore, iron, potassium, calcium, chloride, phosphate, magnesium, sodium, Sulphur, iodine, zinc and copper was added as essential components to baby formula. . Iron is one of the most important components since all babies need a source of iron in their diet. Additionally, vitamins are added to increase the nutritional value of formula. It contains of many vitamins A, B12, C, D, and E as well as thiamine, riboflavin, niacin, pyridoxine, Pantothenate, and Folacin (Ball and Wright, 1999; Picciano, 2001). Our qualitative result found that mothers perceives baby formula as substitute for breast milk, it gives nutrition to support the growth and development of baby but does not build baby's intelligence as advertise in many ads. For this reason, we hypothesize:

\section{H3: Baby formula gives growth benefit significantly affect willingness to pay}


Baby Preference: When baby do not like to milk, they will refuse to take them. After the children stop breastfeeding, they will need to consume milk. Many types of refusal for milk for instance if they have an allergy to cow's milk or simply do not like it. Focus group discussion was held to qualitative explore mothers' perception and understanding about the major interest of milk powder. From the finding of preliminary qualitative research, we predict that baby preference was the effect the willingness to purchase certain brand of baby formula. The author expects the validation of this finding by spreading questionnaires to respondent. Based on the gap it is important to do research on this field.

\section{H5: Baby preference significantly affects willingness to pay}

\section{Methodology}

Cross section study both qualitative and quantitative was conducted in this research. Focus group discussion and sentence completion technique was conducted at the first phase of the study and quantitative study is expected to validate the findings.

Qualitative Study: Focus group discussion was held to qualitative explore mothers' perception and understanding about the major interest of baby formula. A total of 3 subjects (age 29 to 39) were participating from Bandung, West Java. Sentence completion technique also spread online to 25 number of mother. The data were analyzed for identification of common themes and keywords. The information gathered in the preliminary research was used as research framework and to construct the detailed questionnaire that was administered in a survey of 105 mothers.

\section{Propose Research Framework:}

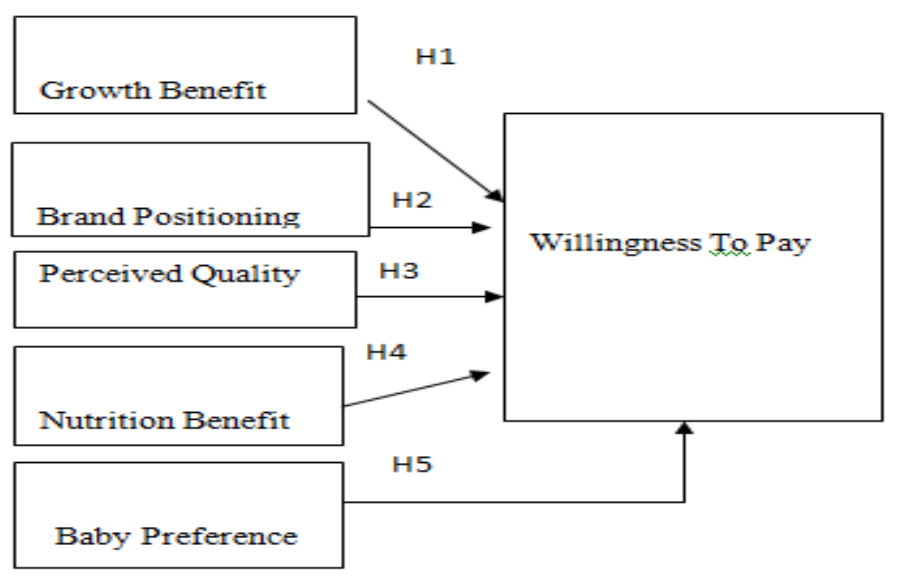

\section{Quantitative Study}

Data Collection: Data used for this research paper were collected through questionnaire administered to 105 mothers of 0 to 5 years old baby, in age range of $25-40$ years. Sample of respondent was taken in West Java province, Indonesia. The survey questionnaire was structured with two parts. The first part included questions related to: socio-demographic information of the respondents such as age, gender, family size, education level and household income. Consumers' purchase behavior in terms of frequency of purchase, important factors to purchase baby formula and source of information for baby formula products. The second part of the questionnaire included the individual perceptions of consumers on various attributes of perceived quality, perceived benefit, perceived price and perceived claim and mothers attitude and intention to purchase on a Likert-type scale to analyze the same opinion on various baby formula attributes ( $1=$ strongly disagree and $5=$ strongly agree $)$.

Data Analysis: The collected data were digitized in an SPSS spreadsheet and a simple statistical analysis to assess the buying behavior, which included descriptive statistical analysis, cross-tabulation and frequency distribution, was carried out. Analysis of Multiple Regression was used to assess to test the significant perception and attitude in baby formula purchase decisions. To assess the mean rank 
difference and the importance of product and market attributes, the Friedman test was conducted. Factor analysis was conducted to identify the underlying dimensions among a set of food product and market attributes. The Principal Component Analysis was done using Varimax rotation criterion. The Kaiser criterion was used to retain factors with Eigen values only greater than one.

\section{Results and Discussion}

This section presents the results of the study. The descriptive analysis discusses the socio-economic profile of the respondents, their perceptions and attitudes, which lead to purchase intention for baby formula. This is followed by the analysis of multiple regressions to determine the level of $95 \%$.

Socio Demography Profiles of Respondents: The personal characteristic of respondent identified by gender, occupation, number of family household, household gross income per month and background education.

Table 1: Demographic characteristic of respondent

\begin{tabular}{lll}
\hline Sample description & Frequency & Percent \\
\hline Sex : & 105 & $100 \%$ \\
Female & & \\
Occupation : & 6 & 5.7 \\
Student & 34 & 32.4 \\
Private Sector & 10 & 9.5 \\
Government sector & 7 & 6.7 \\
General Employee & 12 & 11.4 \\
Entrepreneur & 35 & 33.3 \\
Housewife & & \\
No. of family household : & 60 & 57.1 \\
Person & 30 & 28.6 \\
4 person & 10 & 9.5 \\
6 person & 5 & 4.8 \\
$>5$ person & & \\
Household's gross income per month & & 15.2 \\
& 16 & 31.4 \\
Less than 3 million & 33 & 17.1 \\
3-6 million & 18 & 16.2 \\
$6-9$ million & 17 & 20 \\
$9-12$ million & 21 & \\
Above 12 million & & 6.7 \\
Background Education : & 7 & 16.2 \\
Senior High school & 17 & 59 \\
Diploma & 62 & 18.1 \\
Degree (S1) & 19 & \\
Master (S2) & & \\
\hline Note: $=105$ & &
\end{tabular}

Note: $N=105$

As shown in Table 1, all of the respondents were female (100\%), we eliminate male and single female respondent from this research, we argue that that single female, male and even father's perception and attitude will be different with mothers. The respondents' occupations were $60 \%$ working mother and $33 \%$ fulltime housewives. Majority of the respondents (85.7\%) interviewed were young family who has 3 - 4 person in the household. From the survey, most of the respondents $(93,3 \%)$ have graduate college or university. Most of respondent income was below IDR 9 million (46.65\%).

Important factors to purchase milk powder Analysis: From many attributes of baby formula that we find from qualitative study, we want to test which factors play as most important that influence the decision to purchase baby formula. 
Table 2: Important attributes to purchase baby formula Important factors (descending order, according to "most important" responses)

\begin{tabular}{lll}
\hline Factors & Frequency & Percent \\
\hline Nutrition Content & 40 & 38.1 \\
Suitable and baby preference & 28 & 26.7 \\
Expert recommendation & 14 & 13.3 \\
Product Quality & 8 & 7.6 \\
Benefit of Milk powder & 7 & 6.7 \\
Price & 3 & 2.9 \\
Brand & 2 & 19 \\
Availability & 1 & 1.0 \\
Others & 2 & 1.9 \\
\hline
\end{tabular}

Note: Values are expressed as \%

The results in Table 2 indicate that the most important attributes for mother to purchase baby formula is the nutrition content (38.1\%) follow by suitable and baby preferences $(26.7 \%)$ and $13.3 \%$ respondent stated that it is important when recommend by the expert (doctor, nurse and health practitioners). Indonesian mothers belief that breast milk is the best food for baby, the baby formula is consider as substitute of breast milk. Recognizing the health, financial and other benefits of breastfeeding, public health practitioners have developed numerous interventions to increase breastfeeding rates in the Indonesia. These interventions aim to increase women's interest in breastfeeding and their ability to do so by addressing barriers to breastfeeding for new mothers, in the hospital, in the workplace and at many other levels.

Source of Information of baby formula: In order to know the source of information of baby formula, we gain the data from questionnaire

Table 3: Source of information of baby formula (descending order, according to frequency responses to the question)

\begin{tabular}{lll}
\hline & Frequency & Percent \\
\hline Media (TV, newspaper, magazine, radio) & 46 & 43.0 \\
Health Practitioners' (doctor, nurse, midwife) & 22 & 20.6 \\
Friends / Family & 21 & 19.6 \\
Online mothers discussion & 12 & 11.2 \\
Internet & 4 & 3.7 \\
\hline
\end{tabular}

$N=105$ and Values are expressed as $\%$

The findings of this study have identified that the most frequently encountered source for information on baby formula is from the traditional media. Twenty per cent of all subjects had received nutrition information from their personal health practitioners and TV being the most frequently accessed media sources. In contrast to the results of studies in develop countries such as those in the European Union (De Almeida, 1997) subjects placed a relatively large degree of trust in the radio and TV as providing reliable information (magazines and newspapers were not viewed to be trustworthy sources). The finding that the media is a popular source of information for baby formula has both positive and negative implications. The negative aspect relates to the possibility of the consumer being exposed to and trusting of nutrition information that is unscientific, misleading or designed in such a way as to promote the unscrupulous sale of a product. Consumers, particularly those with lower educational levels, may not be able to distinguish between information provided in marketing campaigns, and that of nutrition education. The high frequency of access to the media for nutrition information for baby formula is to be expected, thus it is imperative for health education and government agencies to reinforce health education. 


\begin{tabular}{|c|c|c|c|c|}
\hline Question & Min & Max & Mean & Std Deviation \\
\hline $\begin{array}{l}\text { With health claim is safer compare to those } \\
\text { with no health claim }\end{array}$ & 1 & 5 & 3.361 & 1.225 \\
\hline $\begin{array}{l}\text { I think the benefit claim on the label is } \\
\text { marketing trick } \\
\text { Sophisticated claim on the packaging attract }\end{array}$ & 1 & 5 & 3.581 & 1.191 \\
\hline me & 1 & 5 & 3.542 & 1.193 \\
\hline I consider baby formula expensive & 1 & 5 & 3.381 & 1.155 \\
\hline $\begin{array}{l}\text { I give affordable price of baby formula to my } \\
\text { children }\end{array}$ & 1 & 5 & 3.266 & 1.170 \\
\hline $\begin{array}{l}\text { I trust the brand that established } \\
\text { I think baby formula that manufactured }\end{array}$ & 1 & 5 & 3.504 & 1.201 \\
\hline $\begin{array}{l}\text { locally is low quality } \\
\text { High price is perceive as high quality }\end{array}$ & 1 & 5 & 3.876 & 1.044 \\
\hline & 1 & 5 & 3.790 & 1.006 \\
\hline $\begin{array}{l}\text { Baby formula good for growth and } \\
\text { development of baby }\end{array}$ & 1 & 5 & 4.000 & 0.898 \\
\hline Baby formula is to give nutrition & 1 & 5 & 4.723 & 0.642 \\
\hline $\begin{array}{l}\text { Baby preference is the main consideration } \\
\text { for me to purchase formula }\end{array}$ & & & & \\
\hline $\begin{array}{l}\text { I am willing to purchase baby formula to my } \\
\text { baby }\end{array}$ & 1 & 5 & 4.066 & 0.835 \\
\hline
\end{tabular}

Result of Factor Analysis: Next table will explain the result and items constructing factor from the result of valid factor analysis. Four factors were extracted to support the qualitative finding.

Table 5: Validity analysis of developed scales

\begin{tabular}{|c|c|c|c|c|c|c|}
\hline Variables & KMO & $\begin{array}{l}\text { Barlett } \\
\left(\mathrm{X}^{2}\right)\end{array}$ & df & Sig & $\begin{array}{l}\text { Created } \\
\text { Factor }\end{array}$ & $\begin{array}{l}\text { Total } \\
\text { Extracted } \\
\text { Variance }\end{array}$ \\
\hline $\begin{array}{l}\text { Brand's } \\
\text { Positioning }\end{array}$ & 0.730 & 372.189 & 55 & 0.000 & 1 & 57.898 \\
\hline $\begin{array}{l}\text { Perceived Quality } \\
\text { Growth Benefit }\end{array}$ & $\begin{array}{l}.500 \\
\mathrm{a}\end{array}$ & 11.415 & 1 & 0.001 & 1 & 66.232 \\
\hline Nutrition Benefit & $\mathrm{a}$ & & & & & \\
\hline $\begin{array}{l}\text { Children } \\
\text { Preferences }\end{array}$ & $\mathrm{a}$ & & & & & \\
\hline
\end{tabular}

To verify the grouping of the indicator variable represent the construct and examine validity the construct, Factor analysis conducted by applied principal component extraction method with varimax rotation, Eigen values over 1 and extracted by factor loading greater than 0.45 for a sample size of 105 respondents (Hair et al., 2010). The result of factor analysis measured by Kaisers-Meyer-Olkin (KMO) $t$ and Barlett's test of spehericity, where value of KMO below 0.50 are not acceptable (Hair et al., 2010). This means developed scale was adequate. The factor loading of each item indicator of construct have significant factor loading with all item loading and conclude that the developed scale were suitable.

We next performed a regression analysis with use willingness to pay as the dependent variable, and the other five "subjective" scales in (table 7) as independent variables. The regression results related are summarized in the following Table 7. Among the five beta coefficient perceive all construct are positively correlated, but only baby formula to give benefit growth significantly associated with mothers attitude (beta coefficient $=.209, \mathrm{t}=2.108, p<.005$ ). 
Table 6: Factor loading of developed scales

\begin{tabular}{|c|c|c|}
\hline Construct & Item Indicator & $\begin{array}{l}\text { Factor } \\
\text { Loading }\end{array}$ \\
\hline \multirow[t]{6}{*}{$\begin{array}{l}\text { Brand } \\
\text { Positioning }\end{array}$} & $\begin{array}{l}\text { Baby formula that give health claim is safer compare to those with no } \\
\text { health claim }\end{array}$ & -.693 \\
\hline & $\begin{array}{l}\text { Baby formula products that give health and benefit claim on the label is } \\
\text { marketing trick }\end{array}$ & .820 \\
\hline & Sophisticated claim on the packaging attract me & .825 \\
\hline & I consider baby formula expensive & -.766 \\
\hline & I give affordable price of baby formula to my children & -.539 \\
\hline & I trust the brand that established & .874 \\
\hline Perceived & With health claim is safer compare to those with no health claim & 0.814 \\
\hline Quality & I think the benefit claim on the label is marketing trick & 0.814 \\
\hline Growth & Baby formula good for growth and development of baby & \\
\hline $\begin{array}{l}\text { BDenent } \\
\text { Nutrition }\end{array}$ & Baby formula is to give nutrition & \\
\hline Benefit & & \\
\hline $\begin{array}{l}\text { Baby } \\
\text { Preference }\end{array}$ & Baby preference is the main consideration for me to purchase formula & \\
\hline
\end{tabular}

Table 7: Regression coefficient and Multicolinearity test:

\begin{tabular}{llll}
\hline Variables & Beta & t-value & Sig \\
\hline Constant & & 2.718 & .008 \\
Brand Positioning & -.023 & -.224 & .823 \\
Perceived Quality & -.015 & -.144 & .886 \\
Growth Benefit & .209 & 2.108 & $.038^{* *}$ \\
Nutrition Benefit & .014 & .134 & .894 \\
Children Preference & .016 & .154 & .878 \\
\hline
\end{tabular}

Table 7 shows that growth benefit is the only factor that influence significantly willingness mothers to purchase baby formula. So, growth benefit is the significant predictors of willingness to purchase baby formula.

Table 8: Hypothesis Testing:

\begin{tabular}{lll}
\hline Determinant Purchase Intention & Hypothesis & Test Result \\
\hline Brand & H1 & Negative and not significant \\
Quality & H2 & Negative and not significant \\
Growth & H3 & Positive and significant \\
Nutrition & H4 & Positive but not significant \\
Children Preference & H5 & Positive but not significant
\end{tabular}

Ns : not significant $; \mathrm{s}=$ significant at $\mathrm{p}<0.05$

Table 8 summarizes the test results of our hypotheses. Our findings support only one of our hypotheses (H3). Specifically, our respondents have shown a significantly great tendency of high attitude to for baby formula because baby formula gives nutrition benefit to support the growth and development of the infant. It appears that baby formula that give benefit for the growth and development of infant is perceived as critical factors to feed baby with baby formula.

\section{Conclusion}

Many as 79\% of participants agree with the statement that baby formula not responsible for baby's intelligence as claim in many advertisements. Mother perceived that baby intelligence is genetic; it is not as an effect consumption of baby formula. To give baby formula for the infant for support the growth and 
development of baby significantly affect mothers attitude to purchase baby formula. This finding consistent with previous research made by Burton et al., (1994) that among 13 list of factors in food decision, vitamins and mineral were mentioned by 76 percent of respondent. The most frequently encountered source of nutrition information among mothers in west java province, Indonesia is the traditional media. Health professionals are considered important as source of information for baby formula too. To address various perceptions towards baby formula it is recommended that health and nutrition practitioners become more actively involved with the training of health professionals, particularly those engaged in delivery of infant services at primary care level, and in turn encourage health professionals to engage more with media sources.

Managerial Implication: From the finding, the marketer in baby formula product must emphasize to advertise the importance of nutrition for the growth and development of infant. Labelling baby formula product with complete list of nutrition can help for shopping cues to mother. On the other hand, for government agencies and health practitioners, the need for nutrition, growth and development education to be included as part of the multi-pronged approach aimed at reducing the prevalence of these preventable micronutrient-related disorders for infant.

Further Research: Given the finding of this research, the impact of commercial advertising, through the $\mathrm{TV}$, radio, as well as through the written media (magazines, newspapers, and information on label of the product), on the baby formula product needs warrants investigation. The credibility of nutrition information for baby's formula and products need to identify.

\section{References}

Angulo, A. M., Gil, J. M. \& Taniburo, L. (2005), Food safety and consumers' willingness to pay for labelled beef in Spain. Journal of Food Products Marketing, 11(3), 89-105.

Anne, F. J. (2011). An Investigation Of Baby Formula Marketing Practises In the Health Care Setting. Thesis by undergraduate student faculty of The University of North Carolina at Chapel Hill, United States.

Ball, T. M. \& Wright, A. L. (1999). Health care costs of formula feeding in the first year of life. Pediatrics, $103(4 / 2), 870-876$.

Becker, F. \& Tilman, I. (2000). Consumer perception of fresh meat quality: a framework for analysis. British Food Journal, 102(3), 158 - 176

Burton, S., Biswas, A. \& Netemeyer, R. G. (1994). Effects of Alternative Nutrition Label Formats and Nutrition Reference Information on Consumer Perceptions, Comprehension, and Product Evaluations. Journal of Public Policy \& Marketing, 13, 36-47.

Calfee, J. E. \& Pappalardo, J. K. (1991). Public Policy Issues in Health Claims for Foods. Journal of Public Policy \& Marketing, 10, 33-53.

Caswell, J. A., Ning, Y., Liu, F. \& Mojduszka, E. M. (2003). The Impact of New Labeling Regulations on the Use of Voluntary Nutrient-Content and Health Claims by Food Manufacturers. Journal of Public Policy \& Marketing, 22, 147-58.

De Almeida, M. D. V., Graca, P., Lappapainen, R., Kafatos, A., Remaut-de-Winter, A. M. \& Kearney, J. M. (1997). Sources used and trusted by nationally representative adults in the European Union for information on healthy eating. European Journal of Clinical Nutrition, 51(2), S16-22

Eagly, A. H. \& Chaiken, S. (1993). The Psychology of Attitudes. Fort Worth, TX: Harcourt Brace Jovanovich.

Fishbein, M. \& Ajzen, I. (1975). Belief, Attitude, Intention and Behaviour, Addison-Wesley, Reading, MA.

Fournier, S. (1998). Consumers and their brands: developing relationship theory in consumer research. Journal of Consumer Research, 24(4), 343-73.

Gartner, L. M., Morton, J., Lawrence, R. A., Naylor, A. J., O'Hare, D., Schanler, R. J. \& Eidelman, A. I. (2005). Breastfeeding and the use of human milk. Pediatrics, 115(2), 496-506.

Govindasamy, R., DeCongelio, M. \& Bhuyan, S. (2005). An evaluation of consumer willingness to pay for organic produce in the Northeastern US. Journal of Food Products Marketing, 11(4), 3-20.

Hair, J. F. Jr., Anderson, R. E., Tatham, R. L. \& Black, W. C. (2010). Multivariate Data Analysis, New Jersey: Prentice Hall International Hans Martin Norberg, Natalia Maehle and Tor Korneliussen (2011). From commodity to brand: antecedents and outcomes of consumers' label perception. Journal of Product \& Brand Management, 2(5), 368-378.

Juran, J. M. (1979). Quality Control Handbook, McGraw-Hill, New York, NY.

Laroche, M. \& Howard, J. A. (1980). Nonlinear relations in a complex model of buyer behavior. Journal of Consumer Research, 6(4), 377-88. 
Levy, A. S. (1995). PHS Food Label Health Claims Focus Group Report: Executive Summary, Food and Drug Administration, Center for Food Safety and Applied Nutrition, Division of Market Studies.

Lichtenstein, D., Blonch, D. \& Black, W. (1988). Correlates of price acceptability. Journal of Consumer Research, 15(2), 243-52.

Okazaki, S., Katsukura, A. \& Nishiyama, M. (2007). How mobile advertising works: the role of trust in improving attitudes and recall. Journal of Advertising Research, 47(2), 165-78.

Picciano, M. F. (2001). Nutrient composition of human milk. Pediatric Clinics of North America, 48, 53-67.

Posri, W., Shankar, B. \& Chadbunchachai, S. (2007). Consumer attitudes towards and willingness to pay for pesticide residue limit compliant 'safe' vegetables in Northeast Thailand. Journal of International Food and Agribusiness Marketing, 19(1), 81-101.

Mazis, M. B. \& Raymond, M. A. (2007). Consumer perceptions of health claims in advertisments and on food labels. The Journal of Consumer Affairs, 31(1), 10-26.

Misra, S., Huang, C. \& Ott, S. (1991), Georgia consumers' preference for organically grown fresh produce. Journal of Agribusiness, 9(2), 53-65.

Moorman, C. (1996). A Quasi Experiment to Assess the Consumer and Informational Determinants of Nutrition Information Processing Activities: The Case of the Nutrition Labeling and Education Act. Journal of Public Policy \& Marketing, 15, 28-44.

Schultz, D. E., Tannebaum, S. I. \& Lauterborn, R. F. (1993). Integrated Marketing Communications, Chicago: NTC Publishing.

Roe, R. \& Sheldon, I. (2007). Credence good labelling: the efficiency and distributional implications of several policy approaches. American Journal of Agricultural Economics, 89(4), 1020-33.

Tsakiridou, E., Zotos, Y. \& Mattas, K. (2006). Employing a dichotomous choice model to assess willingness to pay (WTP) for organically produced products. Journal of Food Products Marketing, 12(3), 5969.

Underhill, S. \& Figueroa, E. (1996). Consumer preferences for non-conventional grown produce. Journal of Food Distribution Research, 27(2), 56-66.

Van Ravenswaay, E. O. \& Hoehn, J. P. (1991). The impact of health risk information on food demand: a case study of ALAR and apples in Caswell, J.A. (Ed.), Economics of Food Safety, Elsevier Science Publishing, New York, NY, 155-74.

www.datastatistik-indonesia.com 


\begin{tabular}{|c|c|c|c|c|}
\hline Variable & Sub Variable & Indicators & Scale & Measurement \\
\hline \multirow[t]{12}{*}{ Perception } & Brand Positioning & $\begin{array}{l}\text { With health claim is } \\
\text { safer compare to those } \\
\text { with no health claim }\end{array}$ & Ordinal & $1-5$ \\
\hline & & $\begin{array}{l}\text { I think the benefit } \\
\text { claim on the label is } \\
\text { marketing trick }\end{array}$ & Ordinal & $1-5$ \\
\hline & & $\begin{array}{l}\text { Sophisticated claim on } \\
\text { the packaging attract } \\
\text { me }\end{array}$ & Ordinal & $1-5$ \\
\hline & & $\begin{array}{l}\text { I consider baby } \\
\text { formula expensive }\end{array}$ & Ordinal & $1-5$ \\
\hline & & $\begin{array}{l}\text { I give affordable price } \\
\text { of baby formula to my } \\
\text { children }\end{array}$ & Ordinal & $1-5$ \\
\hline & & $\begin{array}{l}\text { I trust the brand that } \\
\text { established }\end{array}$ & Ordinal & $1-5$ \\
\hline & Perceived Quality & $\begin{array}{l}\text { I think baby formula } \\
\text { that manufactured } \\
\text { locally is low quality }\end{array}$ & Ordinal & $1-5$ \\
\hline & & $\begin{array}{l}\text { High price is perceive } \\
\text { as high quality }\end{array}$ & Ordinal & $1-5$ \\
\hline & Growth Benefit & $\begin{array}{l}\text { Baby formula good for } \\
\text { growth and } \\
\text { development of baby }\end{array}$ & Ordinal & $1-5$ \\
\hline & Nutrition growth & $\begin{array}{l}\text { Baby formula is to give } \\
\text { nutrition }\end{array}$ & Ordinal & $1-5$ \\
\hline & Baby Preference & $\begin{array}{l}\text { Baby preference is the } \\
\text { main consideration for } \\
\text { me to purchase } \\
\text { formula }\end{array}$ & Ordinal & $1-5$ \\
\hline & WTP & $\begin{array}{l}\text { I am willing to } \\
\text { purchase baby formula } \\
\text { to my baby }\end{array}$ & Ordinal & $1-5$ \\
\hline
\end{tabular}

